\title{
Teucrium polium extracts stimulate GLUT4 translocation to the plasma membrane in L6 muscle cells
}

\author{
Sleman Kadan ${ }^{1,2}$, Yoel Sasson ${ }^{2}$, Raed Abu-Reziq ${ }^{2}$, Bashar Saad ${ }^{1,3}$, Shoshana Benvalid ${ }^{4}$, \\ Thomas Linn ${ }^{5}$, Guy Cohen ${ }^{6}$ and Hilal Zaid ${ }^{1,3 *}$
}

${ }^{1}$ Qasemi Research Center, Al-Qasemi Academic College, P.O Box 124, Baqa El-Gharbia 30100, Israel.

${ }^{2}$ Institute of Chemistry, Casali Center for Applied Chemistry, the Hebrew University of Jerusalem, Givat Ram, Jerusalem 91904, Israel.

${ }^{3}$ Faculty of Sciences, Arab American University Jenin, P.O Box 240, Jenin, Palestine.

${ }^{4}$ Regional Research and Development Center, Judea Center, Kiryat Arba 90100, Israel.

${ }^{5}$ Clinical Research Unit, Center of Internal Medicine, Justus Liebig University, Giessen, Germany.

${ }^{6}$ The Skin Research Institute, Dead-Sea \& Arava Science Center 86910, Israel.

Accepted 30 January, 2018

\begin{abstract}
Teucrium polium L. (TP) is recommended by herbal and integrative practitioners for the treatment of diabetes. However, its mechanism of action in stimulating GLUT4 activity and translocation to the plasma membrane is still unknown. This in vitro study examined the chemical composition, cytotoxicity, and antidiabetic activity of three TP distinct extracts: water/ethanol (WTP), methanol (MTP), and hexane (HTP). The compositions of the TP extracts were determined by GC/MS. MTT and LDH assays were used to assess the toxicity of the extracts. The efficacies of the TP extracts in enhancing glucose transporter-4 (GLUT4) translocation to plasma membrane (PM) were tested in L6 muscle cells, stably expressing myctagged GLUT4 using the cell-ELISA test. GC/MS phytochemical analysis of MTP and HTP extracts revealed 10 compounds in each extract, and only palmitic acid was communal in these two extracts. WTP, MTP, and HTP extracts were safe up to 63, 63, and $250 \mu \mathrm{g} / \mathrm{ml}$, respectively. The HTP extract was the most efficient in GLUT4 translocation enhancement, while the least efficient was the WTP extract. In addition, the HTP extract increased the GLUT4 translocation at $32 \mu \mathrm{g} / \mathrm{ml}$ by 2- and 3-fold relative to the control in the absence and presence of insulin, respectively. A similar result was obtained with the MTP extract at $63 \mu \mathrm{g} / \mathrm{ml}$. In contrast, WTP extract in the presence of insulin had no effect and in the absence of insulin had slightly enhanced GLUT4 translocation. These findings indicate that TP antidiabetic activity is mediated in part by enhancing GLUT4 translocation to the PM in skeletal muscle.
\end{abstract}

Keywords: GLUT4, GC/MS, phytochemicals, diabetes, Teucrium polium.

*Corresponding author. E-mail: E-mail: hilalz@qsm.ac.il. Tel: +972-4-6286761/5. Fax: +972-4-6286762.

\section{INTRODUCTION}

Herbal-based antidiabetic medicines have been a part of traditional medicine for centuries. The Chinese were the first to detect diabetes mellitus in the third century, and they noticed that the sweetness of urine attracts dogs. Later, Indian physicians in the sixth century related to diabetes as Honey urine and prescribed several herbs to treat it (Saad et al., 2017; Zaid and Saad, 2013).
Diabetes was then recognized by medieval Greco-Arab physicians by its main symptoms: increased thirst, frequent urination, and tiredness. Greco-Arab physicians and practitioners then used a series of medicinal plants for treating these combined symptoms (Saad et al., 2017; Zaid and Saad, 2013).

Modern treatment of diabetes mellitus revolves around 
controlling blood glucose levels either through glucose production or use, through increasing insulin secretion and effectiveness, reducing energy intake, or increasing energy expenditure (Kadan et al., 2013; Zaid et al., 2008). Unidirectional glucose uptake into skeletal muscle is mediated by the facilitative glucose transporter-4 (GLUT4), a membrane protein that continuously recycles between intracellular vessels and the plasma membrane (PM). Insulin receptor mediated signals significantly enhance the rate of GLUT4 traffic towards and fusion with the PM; this process is called GLUT4 translocation (Zaid et al., 2008).

Reports on natural herbs for diabetes treatment focus on lowering blood sugar and reducing the damaging effects of the disease. Interestingly, a single medicinal plant may include biochemically different antidiabetic mechanisms to stimulate insulin secretion; inhibit intestinal carbohydrate digestion and absorption; and enhance GLUT4 translocation to the plasma membrane, insulin sensitivity, and activation of MAPK and PPAR $\gamma$. Some antidiabetic herbs even possess anti-inflammatory and immunomodulatory action (Ota and Ulrih, 2017; Rios et al., 2015; Saad et al., 2017; Zaid et al., 2016).

Insulin sensitizers include plants that increase glucose uptake and disposal by muscle, fat, and hepatic cells, as well as cells that regulate the hepatic glycogen metabolism. We had recently tested the mechanism of action of several medicinal plant extracts in increasing the glucose uptake. Trigonella foenum-graecum, Urtica dioica, Atriplex halimus, Cinnamomum officianalis (Kadan et al., 2013), and Ocimum basilicum (Kadan et al., 2016) increased glucose disposal by enhancing the glucose transporter 4 (GLUT4) translocation to the plasma membrane.

Teucrium polium L. (TP) is one of the most used antidiabetic herbs, and it is a wild-growing flowering plant in the temperate parts of Europe, Africa, and Asia (mainly the Middle East) (Bahramikia and Yazdanparast, 2012). In Greco-Arab medicine, TP has been used for different pathological conditions including inflammation, gastrointestinal disorders, rheumatism, and diabetes mellitus (Saad et al., 2017). TP antidiabetic activity was evaluated in animal models, and some studies in diabetic animal models have shown that intravenous, intraperitoneal, or oral administration of a TP crude extract to STZ-induced diabetic rats significantly decreased serum glucose levels (Esmaeili and Yazdanparast, 2004; Gharaibeh et al., 1988; Shahraki et al., 2007). T. polium ethanol/water extract fed-diabetic rats experienced significant reductions in serum glucose levels and blood insulin level was enhanced by almost $160 \%$ (Shahraki et al., 2007). Gavage and oral administration of a hydroalcoholic and water extract of TP increased insulin secretion from rat-isolated islets (Mohseni Salehi Monfared and Pournourmohammadi, 2010) and insulin levels in rats (Esmaeili and Yazdanparast, 2004; Mohseni Salehi Monfared and Pournourmohammadi, 2010; Tabatabaie and
Yazdanparast, 2017). T. polium crude extract enhanced insulin secretion by almost $135 \%$ after a single dose of plant aqueous extract (Esmaeili and Yazdanparast, 2004). In addition, TP ethyl acetate extract decreased serum, liver, and muscle triglyceride content of sucroseinduced insulin resistance in rats (Mousavi et al., 2012). In the present study, the role of GLUT4 translocation in the traditionally known antidiabetic effects of TP was evaluated.

\section{MATERIALS AND METHODS}

\section{Plant extract preparation}

T. polium (aerial parts) were purchased from Al Alim- Medicinal Herb Center, Zippori, Israel. TP air-dried aerial parts $(40 \mathrm{~g})$ were powdered, packed in an Erlenmeyer flask, and extracted in $500 \mathrm{ml}$ with $50 \%$ ethanol in water (WTP), methanol (MTP), or hexane (HTP) at room temperature for $72 \mathrm{~h}$ to give a dark green extract. The methanol extract was filtered and concentrated by a rotary vacuum evaporator under pressure at $50^{\circ} \mathrm{C}$. The hexane extract was filtered and evaporated to dryness under pressure at $50^{\circ} \mathrm{C}$ and dissolved in DMSO for further studies. The water/ethanol was not concentrated. The yield of the extracts was $6.3,11.1$ and $4.6 \%$ for WTP, MTP and HTP extracts, respectively. The stock extracts were then preserved in airtight glass containers and kept at $-20^{\circ} \mathrm{C}$.

\section{Gas chromatography-mass spectrometry analysis}

GC/MS analysis was performed with HP5890 Series II GC equipped with a Hewlett-Packard MS Engine (HP5989A) single quadrupole MS, HP7673 auto sampler, HP MS-DOS Chemstation, and HP-5MS capillary column $(0.25 \mu \mathrm{m} \times 15 \mathrm{~m} \times 0.25 \mathrm{~mm})$. The temperature program was as follows: injector temperature, $180^{\circ} \mathrm{C}$; initial temperature, $40^{\circ} \mathrm{C}$ for $6 \mathrm{~min}$; gradient of $20^{\circ} \mathrm{C} / \mathrm{min}$ until $140^{\circ} \mathrm{C}$; gradient of $10^{\circ} \mathrm{C} / \mathrm{min}$ until $200^{\circ} \mathrm{C}$; and hold time, $3 \mathrm{~min}$. The MS parameters were set as follows: source temperature, $180^{\circ} \mathrm{C}$; transfer line, $280^{\circ} \mathrm{C}$; positive ion monitoring; and El-MS $(70 \mathrm{eV})$.

\section{Identification of components}

The percentage composition of the samples was computed from the GC peak areas, and library searches were performed using the NIST GC/MS Library, and the mass spectra from the literature were compared with the compositions (spectra) of the samples to define them. Component relative percentages were calculated based on GC peak areas without using correction factors.

\section{Cell culture}

Cells from the rat L6 muscle cell line, stably expressing myc-tagged GLUT4 (L6-GLUT4myc; a kind gift from Prof. Amira Klip) (Zaid et al. 2009), were maintained in myoblast monolayer culture. All cells were grown under an atmosphere of $95 \%$ air and $5 \% \mathrm{CO}_{2}$ in $\alpha$ MEM supplemented with $10 \%$ fetal bovine serum (FBS), $100 \mathrm{U} / \mathrm{ml}$ penicillin, and $0.1 \mathrm{mg} / \mathrm{ml}$ streptomycin.

\section{MTT and lactate dehydrogenase (LDH) assays}

Cells were subcultured into 96-well plates with $200 \mu$ of medium (2 $\times 10^{4} /$ well $)$ for $24 \mathrm{~h}$ and then exposed to $(0$ to $1 \mathrm{mg} / \mathrm{ml})$ of TP extracts. Cell viability was assessed by following the amount of 
formazan dye formed in alive cells (MTT) or by calculating the relevant activity of $\mathrm{LDH}$ released in dead cells, as described previously (Kadan et al., 2013). MTT and LDH kits were purchased from Promega (WI, USA).

\section{Determination of surface GLUT4myc}

Surface myc-tagged GLUT4 was measured in intact, nonpermeabilized cells. Cells grown in 24-well plates for one day followed by the addition of the plant extracts for $20 \mathrm{~h}$ and serumstarved for $3 \mathrm{~h}$ were treated with or without $1 \mu \mathrm{M}$ insulin for $20 \mathrm{~min}$. GLUT4myc on the plasma membrane was then detected as previously described (Zaid et al., 2009). Briefly, the cells were reacted with polyclonal anti-myc antibody (1:200) (from SigmaAldrich) for $1 \mathrm{~h}$ at $4^{\circ} \mathrm{C}$, washed with PBS, reacted with horseradish peroxidase-bound goat anti-rabbit secondary antibody (1:1000) (from Promega) for $1 \mathrm{~h}$ at $4^{\circ} \mathrm{C}$, and washed with PBS. Cells then were incubated with $0.5 \mathrm{ml}$ of $o$-phenylenediamine dihydrochloride reagent and allowed to develop for 20 to $30 \mathrm{~min}$ in the linear range in the dark at room temperature. The reaction was stopped with 0.5 $\mathrm{ml} /$ well of $3 \mathrm{~N} \mathrm{HCl}$. Supernatants were collected, and absorbance was measured at $492 \mathrm{~nm}$. Background absorbance obtained in the absence of anti-myc antibody was subtracted from all values.

\section{Statistical analysis}

Error bars were plotted and represent simple standard deviations of the mean. When comparing different samples, results were considered to be statistically different when $P<0.05$. T-test statistical calculations were conducted using SPSS version 21.0.

\section{RESULTS}

The current study evaluated the chemical composition, cytotoxicity, and antidiabetic activity of three distinct $T$. polium L. (TP) extracts: water/ethanol (WTP), methanol (MTP), and hexane (HTP).

\section{Teucrium polium L. chemical composition}

The chemical compounds in the HTP and MTP extracts were identified by GC/MS (Table 1), and 19 chemical compounds were detected by GC/MS analysis in TP extracts. They contained a complex mixture of chemical compounds, aromatic, saturated and unsaturated fatty acids, and phenolic compounds. There were 10 compounds detected in the MTP extract, and nine compounds were found in the HTP. Interestingly, only one mutual compound was found in the two extracts, namely, palmitic acid (Table 1). In addition, palmitic acid was recently reported by our group to be found in three different Ocimum basilicum L. extracts (methanol, hexane, and dichloromethane). 0 . basilicam-derived palmitic acid was suggested to play an essential antidiabetic role that seems to be mediated through GLUT4 translocation (Kadan et al., 2016).

As seen in Table 1, (5E,8E,11E)-methyl heptadeca5,8,11-trienoate (5.6\%); (9Z,12Z)-octadeca-9,12-dienoic acid $\quad(4.5 \%) ; \quad 3,7,11$-trimethyldodeca-1,6,10-trien-3-ol $(4.4 \%)$; and Palmitic acid $(4.2 \%)$ are the major compounds in the MTP (Figure 1C). In the HTP, cisvaccenic acid (20\%), butyl (2-ethylhexyl) phthalate $(12.2 \%)$, and Palmitic acid $(7.2 \%)$ are the main components (Figure 2C). Some of the detected compounds were reported to possess antidiabetic activity, namely, thymol (Saravanan and Pari, 2015), carvacrol (Ezhumalai et al., 2014), eugenol (Jeong et al., 2014), and cis-vaccenic acid (Alstrup et al., 2004).

\section{Toxicity of Teucrium polium L. extracts}

MTT and LDH leakage assays were used to evaluate the nontoxic concentrations of the three TP extracts, and the toxicities of the plant extracts were tested in vitro in L6GLUT4myc cells. Cells were seeded in 96 well plates and were subjected to increasing concentrations of the extracts ( 0 to $1 \mathrm{mg} / \mathrm{ml}$ ) for $24 \mathrm{~h}$. Extract concentrations that led to less than $10 \%$ cell death were considered as safe, and WTP (Figure 3A), MTP (Figure 1A), and HTP (Figure 2A) extracts were found to be safe up to 63,63 and $250 \mu \mathrm{g} / \mathrm{ml}$, respectively. The efficacy studies were performed at concentrations equal or less than the safe concentration of each extract.

\section{Effects of Teucrium polium extracts on GLUT4 translocation}

Skeletal muscle and liver are the primary tissues responsible for dietary glucose uptake and disposal. In muscle and hepatic and adipose tissues, insulin promotes the exocytic traffic of intracellular GLUT4 vessels towards the plasma membrane to elicit a rapid increase in glucose uptake (Osorio-Fuentealba and Klip, 2015; Zaid et al., 2008; Zierath et al., 1996). In insulin resistance and type 2 diabetes, insulin fails to promote GLUT4 translocation to the PM, and some of the antidiabetic synthetic drugs and medicinal plants-based products bypass the insulin resistance by increasing GLUT4 translocation in insulin dependent and independent pathways (Zaid et al., 2012).

The involvement of glucose transporter (GLUT4) in the observed antidiabetic effects of $T$. polium extracts was evaluated by applying the GLUT4 translocation assay. In addition, insulin increases the GLUT4 translocation to the myoblasts surface, thus enhancing glucose uptake (Osorio-Fuentealba and Klip, 2015; Zaid et al., 2008). L6 skeletal muscle cell lines expressing myc epitope at the exofacial loop of the GLUT4, named L6-GLUT4myc, were used as a model to demonstrate GLUT4 translocation to the plasma membrane (Zaid et al., 2008). The extracts were added to the L6-GLUT4myc cells in the absence or presence of insulin, and the translocation of GLUT4myc to the plasma membrane was assessed as described in 
Table 1. Chemical composition of Teucrium polium methanol (MTP) and hexane (HTP) extracts.

\begin{tabular}{lccc}
\hline Compound & MTP (\%) & HTP (\%) & ${ }^{*}$ rt \\
\hline Thymol & 1.5 & & 11.49 \\
5-isopropyl-2-methylphenol & 1.6 & & 11.58 \\
Eugenol & 1 & & 12.05 \\
(E)-7,11-dimethyl-3-methylenedodeca-1,6,10-triene & 0.96 & & 13.43 \\
2,6-di-tert-butylphenol & & 0.97 & 13.58 \\
(2E,6E)-3,7,11-trimethyldodeca-2,6,10-trien-1-yl acetate & 1.6 & & 13.67 \\
3,7,11-trimethyldodeca-1,6,10-trien-3-ol & 4.4 & & 13.94 \\
(S)-2-methyl-6-(p-tolyl)hept-2-en-4-one & & 2.2 & 15.04 \\
1,3,5-tri-tert-butylbenzene & & 3.4 & 15.22 \\
2-(tert-butyl)-4-(2,4,4-trimethylpentan-2-yl)phenol & & 5.2 & 16.1 \\
Palmitic acid & 4.2 & 7.2 & 17.3 \\
butyl (2-ethylhexyl) phthalate & & 12.2 & 17.33 \\
(9E,12E,15E)-methyl octadeca-9,12,15-trienoate & 3 & & 18.08 \\
(9Z,12Z)-octadeca-9,12-dienoic acid & 4.5 & & 18.37 \\
cis-vaccenic acid & & 20 & 18.4 \\
(5E,8E,11E)-methyl heptadeca-5,8,11-trienoate & 5.6 & & 18.42 \\
Oleamide & & 2.6 & 19.52 \\
2-(((2-ethylhexyl)oxy)carbonyl)benzoic acid & & 3.1 & 20.31 \\
Henicosane & & 2.2 & 20.76 \\
\hline
\end{tabular}

${ }^{*} \mathrm{rt}$, retention time $(\mathrm{min})$.

the Methods section. Results obtained indicate that insulin-independent (basal) and insulin dependent GLUT4 translocations to the PM in muscle L6-GLUT4myc cells are significantly increased in response to TP extracts, especially the methanol and hexane extracts. The WTP extract was found to have the lowest effects on GLUT4 translocation, and only $20 \%$ of GLUT4 translocation was obtained at $32 \mu \mathrm{g} / \mathrm{ml}$ of WTP extract in the absence of insulin. No effect was observed in the presence of insulin (Figure 3B).

MTP extract $(63 \mu \mathrm{g} / \mathrm{ml})$ increased GLUT4 translocation to the PM by two and three times in the absence and presence of insulin, respectively (Figure 1B). HTP extract (at $32 \mu \mathrm{g} / \mathrm{ml}$ ) led to similar results (Figure $2 \mathrm{~B}$ ) obtained with MTP extract (at $63 \mu \mathrm{g} / \mathrm{ml}$ ). These findings indicate that the HTP extract was the most efficient extract in enhancing GLUT4 translocation.

\section{DISCUSSION}

TP is one of the traditional medicinal plants well known for its antidiabetic property in the Middle East (Saad et al., 2017). TP extracts anti diabetic activity was evaluated in vitro, in vivo and in situ. TP aqueous extract supplemented rats had significant decrease in cornstarch induced acute hyperglycemia $45 \mathrm{~min}$ post starch intragastric administration (Kasabri et al., 2011). TP antidiabetic activity was further evaluated in animal models, and through gavage and oral administration of a hydroalcoholic and water extract of TP, insulin secretion levels increased in the circulating blood in rats (Esmaeili and Yazdanparast, 2004; Mohseni Salehi Monfared and Pournourmohammadi, 2010; Tabatabaie and Yazdanparast, 2017). Insulinotropic properties of TP extracts was attributed to the presence of apigenin (5hydroxy-4', 7-dimethoxyflavone) existing only in methanolic, ethanolic, but not in aqueous/ethanolic and fractions (Mirghazanfari et al., 2010). In this study however, apigenin was the sole compound detected by GC/MS.

The chemical compounds in the HTP and MTP extracts in this study were identified by GC/MS. Ten compounds detected in the MTP extract, and nine compounds were found in the HTP. The extracts contained aromatic, saturated and unsaturated fatty acids, and phenolic compounds. Previous studies have studied the chemical content of TP extracts (Mahmoudi and Nosratpour, 2013; Djabou et al., 2012; Guetata and Al-Ghamdia, 2014). They reported several distinct compound compered to the list of compounds reported here. This could be due to several factors especially the method of extraction and the accuracy of compounds detection by GC/MS. In this study, only compounds that showed at least $90 \%$ similarity to the GC/MS library reference were listed. This explains the short list of compounds listed here. Afifi and colleagues (Afifi et al., 2009) on the other hand have used methanol and hexane in preparing TP extract and yet they detected deferent compounds compared to our list. In addition to the previous possible reasons, we have used deferent extraction method to prepare the extracts and the plants were grown freely in the nature where in 

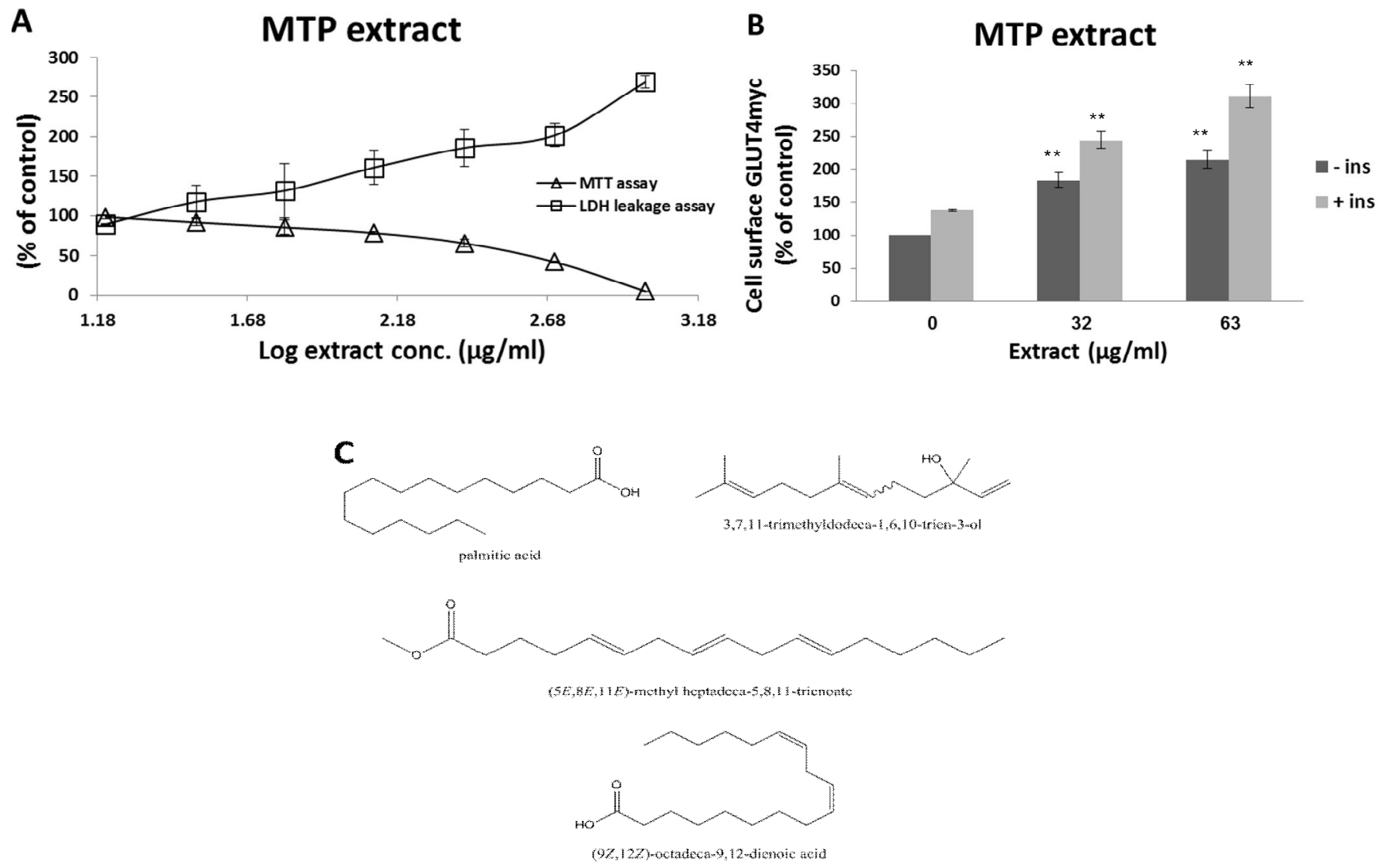

Figure 1. Effect of MTP extract on cell viability (A), GLUT4 translocation (B) and major active compound (C). For measuring cell viability (MTT assay and LDH leakage assay) L6-GLUT4myc cells $(20,000$ cell/well) and exposed to methanol extract for $20 \mathrm{~h}$. For the evaluation of the GLUT4, L6-GLUT4myc cells $(150,000$ cell/well) were exposed to MTP for $20 \mathrm{~h}$. Serum depleted cells were treated without (-) or with (+)1 $\mu \mathrm{M}$ insulin for $20 \mathrm{~min}$ at $37^{\circ} \mathrm{C}$ and surface myc-tagged GLUT4 density was quantified using the antibody coupled colorimetric assay. Chemical composition analysis was carried out using GC/MS analysis. Values given in A and B represent means \pm SEM (\% of untreated control cells) of three independent experiments carried out in triplicates. T-test of statistical calculations were conducted using SPSS version 21.0. ${ }^{* *} p<0.01$, significant as compared with controls.

Afifi's report, some of the plants were grown in greenhouse and they might be collected in defferent season.

Some of the detected compounds in this study were previously reported to possess antidiabetic activity, namely, thymol (Saravanan and Pari, 2015), carvacrol (Ezhumalai et al., 2014), eugenol (Jeong et al., 2014), and cis-vaccenic acid (Alstrup et al., 2004). Moreover, Palmitic acid detected in HTP and MTP was previously reported in active anti diabetic extracts of Ocimum basilicum (Kadan et al., 2016). However, palmitic acid cannot be the sole active compound in HTP and MTP since water extract (where palmitic acid is not expected to be present) also increased GLUT4 activation although it was less effective than HTP and MTP.

TP was reported as the insulin secretion enhancer by regulation transcription factors of the JNK pathway in the pancreatic $\beta$-cells (Tabatabaie and Yazdanparast, 2017). However, TP effect on glucose disposal in muscle cell line was not reported. To the best of the authors' knowledge, this is the first report on the efficacy of the TP extract on GLUT4 activity and translocation to the PM.

Glucose transporter-4 (GLUT4) continuously recycles between the PM and the intra cellular vesicles, and insulin shifts GLUT4 translocation towards the PM. Glucagon, in contrast, shifts GLUT4 translocation towards the intracellular stores (Osorio-Fuentealba and Klip, 2015; Zaid et al., 2008; Zierath et al., 1996). We and others tested the hypoglycemic activity of traditionally used antidiabetic medicinal plants through increasing glucose transporter (GLUT) translocation to the plasma membrane in muscle and hepatic tissue (Kadan et al., 2013, 2016; Ota and Ulrih, 2017; Zaid et al., 2015, 2016). Although TP is recommended by herbal and integrative practitioners for the treatment of diabetes (Mousavi et al., 2015; Saad et al., 2017), the action mechanism whereby TP enhances glucose uptake is not fully understood. Therefore, the present study was conducted to evaluate the role of GLUT4 translocation in the observed antidiabetic TP effects. Three TP extracts (water/ethanol, 


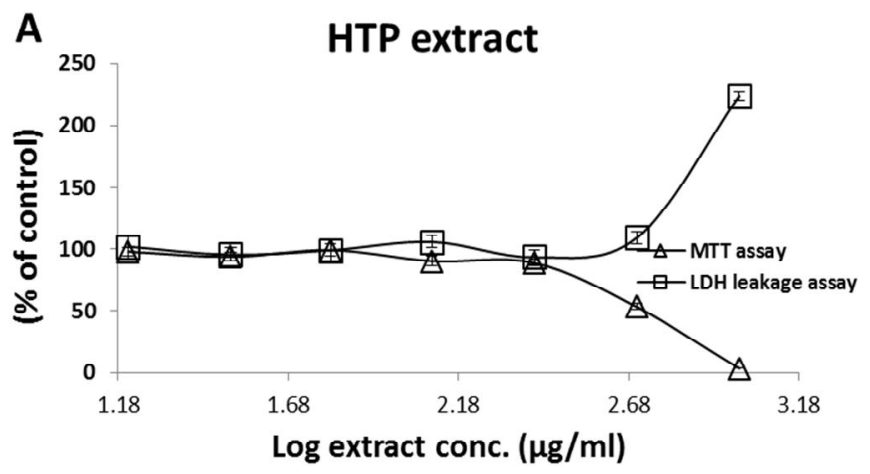

B HTP Extract
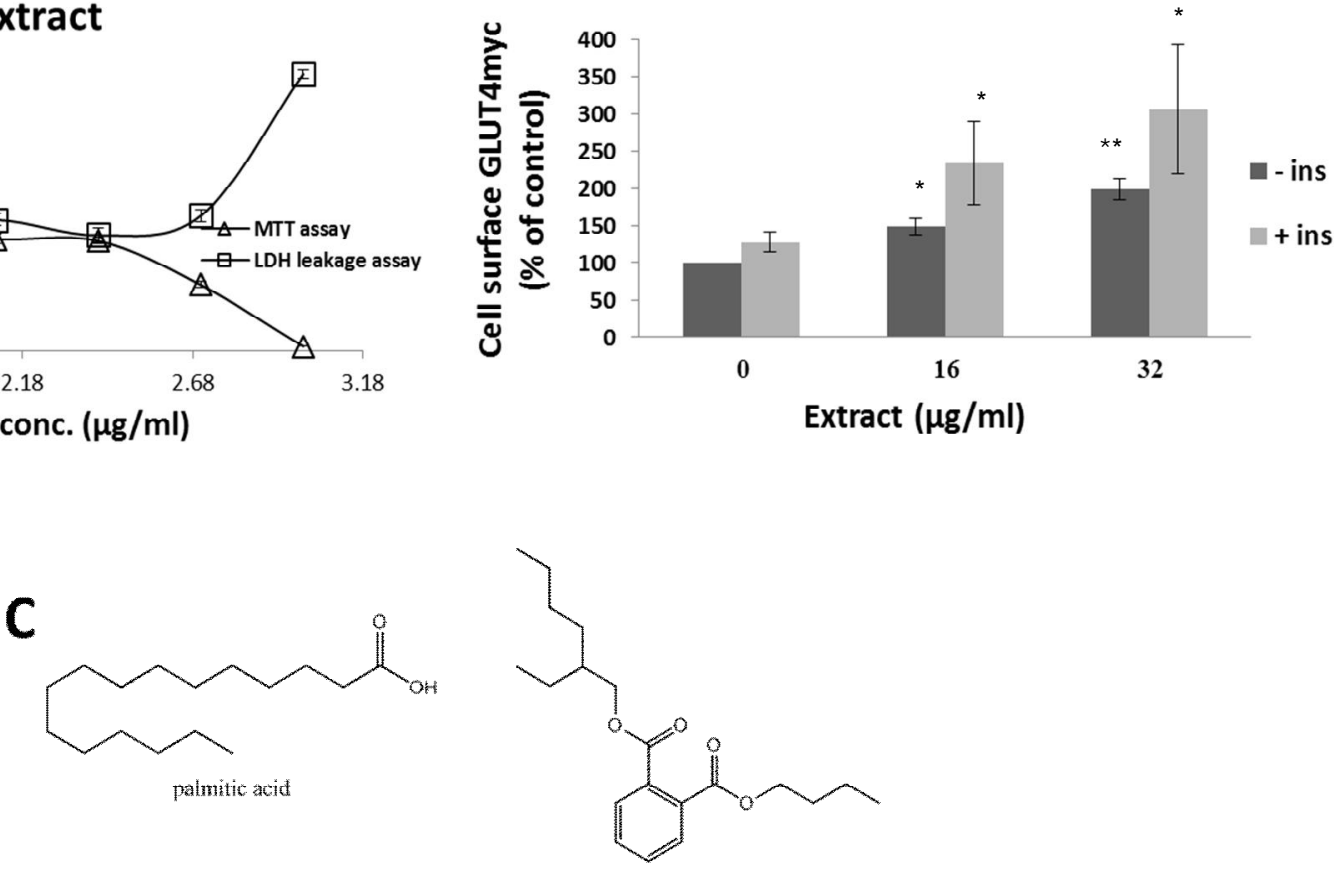

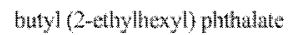<smiles>CCCCCCCCCCCCCCCC(=O)O</smiles>

(Z)-octadeo-11-enoic acid

Figure 2. Effect of HTP extract on cell viability (A), GLUT4 translocation (B) and major active compound (C). For measuring cell viability (MTT assay and LDH leakage assay) L6-GLUT4myc cells $(20,000$ cell/well) and exposed to HTP extract for $20 \mathrm{~h}$. For the evaluation of the GLUT4, L6-GLUT4myc cells (150,000 cell/well) were exposed to HTP extract for $20 \mathrm{~h}$ and tested as described in Fig. 1 legend. Chemical composition analysis was carried out using GC/MS analysis. Values given in A and B represent means \pm SEM (\% of untreated control cells) of three independent experiments carried out in triplicates. T-test of statistical calculations were conducted using SPSS version 21.0. ${ }^{*} p<0.05,{ }^{* *} p<0.01$, significant as compared with controls.

A

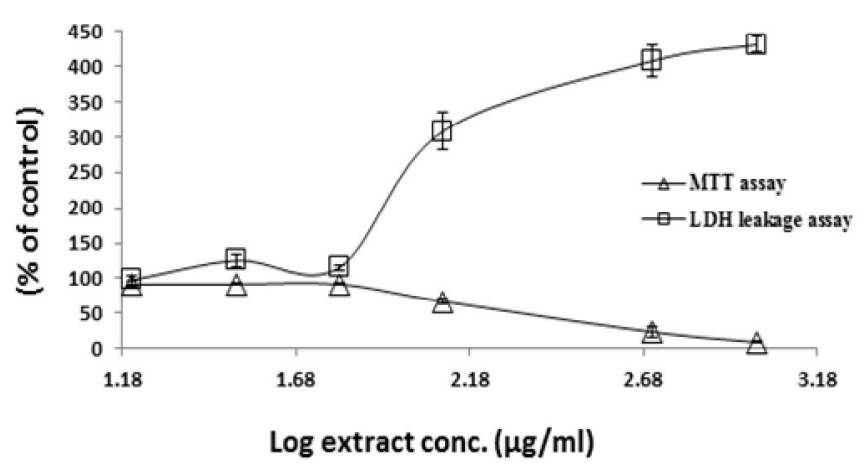

B

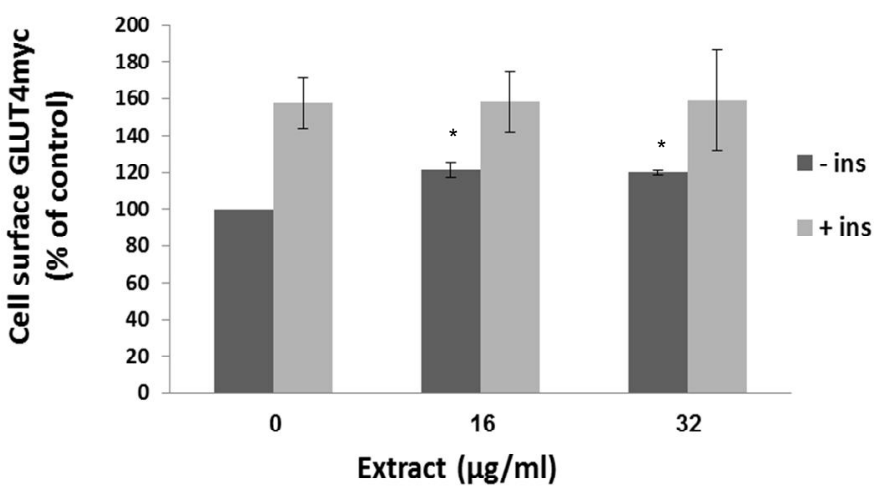

Figure 3. Effect of WTP extract on cell viability (A), GLUT4 translocation (B). For measuring cell viability (MTT assay and LDH leakage assay) L6-GLUT4myc cells (20,000 cell/well) and exposed to methanol extract for $20 \mathrm{~h}$. For the evaluation of the GLUT4, L6-GLUT4myc cells $(150,000$ cell/well) were exposed to methanol extract for $20 \mathrm{~h}$ as described in Figure 1 . T-test of statistical calculations were conducted using SPSS version 21.0. ${ }^{*} p<0.05$, significant as compared with controls. 
methanol, and hexane) were prepared, and their effects on GLUT4 translocation were measured in L6 skeletal muscle cell line in the present and absence of insulin.

The extent of increase in the insulin-stimulated GLUT4 translocation was additive to that of basal GLUT4 translocation in TP-exposed cells, suggesting the possible synergistic effects between the TP active ingredients and the insulin. Alternately, TP active ingredients might activate GLUT4 translocation in noninsulin dependent pathways (e.g., AMP-Kinase). It is then possible that TP active ingredients might possess insulinlike or insulin-sensitizing activity/compounds. It is essential to dissect TP active compounds to identify its cellular molecular target and to show its specific antidiabetic mechanism(s) and cellular pathway(s).

Insulin enhances the mobilization of GLUT4-containing vesicles from intracellular stores to the muscle cell surface and thus promotes glucose uptake. Notably, the gain in GLUT4 at the muscle membrane is reduced in primary cells from diabetic animals and human diabetic subjects (Shamni et al., 2017; Zaid et al., 2008; Zierath et al., 1996). Hence, understanding the action mechanisms of antidiabetic medicinal plants and determining their potential active ingredients are of paramount importance in developing antidiabetic new drugs.

\section{Conclusion}

Phytochemical analysis with GC-MS technique revealed various phytochemicals identities in both MTP and HTP extracts. Some antidiabetic compounds were identified in TP extracts, and these compounds maybe responsible on GLUT4 translocation. Further studies regarding the chemical profile of the most active extract (HTP) will be performed to identify the bioactive compound(s).

\section{ACKNOWLEDGEMENTS}

We are thankful to Prof. Amira Klip (The Hospital for Sick Children, Toronto, Canada) for providing the L6GLUT4myc cells. We would also like to acknowledge AAUJ and Al-Qasemi Research Foundation for providing their financial support. Sleman Kadan appreciates the Ministry of Science, Technology and Space for his scholarship.

\section{REFERENCES}

Afifi FU, Abu-Irmaileh BE, Al-Noubani RA, 2009. Comparative analysis of the essential oils of Teucrium polium L. grown in different arid and semi arid hHabitats in Jordan. Jordan J Pharmaceut Sci, 2(1): 42-52.

Alstrup KK, Brock B, Hermansen K. 2004. Long-term exposure of INS1 cells to cis and trans fatty acids influences insulin release and fatty acid oxidation differentially. Metabolism, 53: 1158-1165.

Bahramikia S, Yazdanparast R, 2012. Phytochemistry and medicinal properties of Teucrium polium L. (Lamiaceae). Phytother Res, 26: 1581-1593.
Djabou N, Muselli A, Allali H, El Amine MD, Varesi BT, Costa J, 2012. Chemical and genetic diversity of two Mediterranean subspecies of Teucrium polium. L. Phytochemistry, 83: 51-62.

Esmaeili M.A, Yazdanparast R, 2004. Hypoglycaemic effect of Teucrium polium: studies with rat pancreatic islets. $J$ Ethnopharmacol, 95: 27-30.

Ezhumalai M, Radhiga T, Pugalendi KV, 2014. Antihyperglycemic effect of carvacrol in combination with rosiglitazone in high-fat dietinduced type 2 diabetic C57BL/6J mice. Mol Cell Biochem, 385: 2331.

Gharaibeh MN, Elayan HH, Salhab AS, 1988. Hypoglycemic effects of Teucrium polium. J Ethnopharmacol, 24: 93-99.

Guetata A, Al-Ghamdia FA, 2014. Analysis of the essential oil of the germander (Teucrium polium L.) aerial parts from the northern region of Saudi Arabia. Int J Appl Biol Pharmaceut Technol, 5(2): 218-135.

Jeong KJ, Kim do Y, Quan HY, Jo HK, Kim GW, Chung SH, 2014. Effects of eugenol on hepatic glucose production and AMPK signaling pathway in hepatocytes and C57BL/6J mice. Fitoterapia, 93: 150-162.

Kadan S, Saad B, Sasson Y, Zaid H, 2016. In vitro evaluation of antidiabetic activity and cytotoxicity of chemically analysed Ocimum basilicum extracts. Food Chem, 196: 1066-1074.

Kadan S, Saad B, Sasson Y, Zaid H, 2013. In vitro evaluations of cytotoxicity of eight antidiabetic medicinal plants and their effect on GLUT4 translocation. Evid Based Complement Alternat Med, 549345.

Kasabri V, Afifi FU, Hamdan I, 2011. In vitro and in vivo acute antihyperglycemic effects of five selected indigenous plants from Jordan used in traditional medicine. J Ethnopharmacol, 133(2): 888896.

Mahmoudi R, Nosratpour S, 2013. Teucrium polium L. essential oil: phytochemical component and antioxidant properties. Int Food Res J, 20(4): 1697-1701.

Mirghazanfari S, Keshavarz M, Nabavizadeh F, Soltani N, Kamalinejad M, 2010. The effect of "Teucrium polium L." extracts on insulin release from in situ isolated perfused rat pancreas in a newly modified isolation method: the role of $\mathrm{Ca}^{2+}$ and $\mathrm{K}^{+}$channels. Iran Biomed J, 144: 178-185.

Mohseni Salehi Monfared SS, Pournourmohammadi S, 2010. Teucrium polium complex with molybdate enhance cultured islets secretory function. Biol Trace Elem Res, 133: 236-241.

Mousavi SE, Shahriari A, Ahangarpour A, Vatanpour H, Jolodar A, 2012. Effects of Teucrium polium ethyl acetate extract on serum, liver and muscle triglyceride content of sucrose-induced insulin resistance in rat. Iran J Pharm Res. 11: 347-355.

Mousavi SM, Niazmand S, Hosseini M, Hassanzadeh Z, Sadeghnia HR, Vafaee F, Keshavarzi Z, 2015. Beneficial effects of teucrium polium and metformin on diabetes-induced memory impairments and Brain tissue oxidative damage in rats. Int J Alzheimers Dis, 493729.

Osorio-Fuentealba C, Klip A, 2015. Dissecting signalling by individual Akt/PKB is oforms, three steps at once. Biochem J, 470: e13-16.

Ota A, Ulrih NP, 2017. An overview of herbal products and secondary metabolites used for management of type two diabetes. Front Pharmacol, 8: 436.

Rios JL, Francini F, Schinella GR, 2015. Natural products for the treatment of type 2 diabetes mellitus. Planta Med, 81: 975-994.

Saad B, Zaid H, Shanak S, Kadan S, 2017. Anti-diabetes and antiobesity medicinal plants and phytochemicals: safety, efficacy, and action mechanisms. Springer International Publishing ISBN 978-3319-54101-3. p. 147-174.

Saravanan S, Pari L, 2015. Role of thymol on hyperglycemia and hyperlipidemia in high fat diet-induced type 2 diabetic C57BL/6J mice. Eur J Pharmacol, 761: 279-287.

Shahraki MR, Arab MR, Mirimokaddam E, Palan MJ, 2007. The effect of Teucrium polium (Calpoureh) on liver function, serum lipids and glucose in diabetic male rats. Iran Biomed J, 11: 65-68.

Shamni O, Cohen G, Gruzman A, Zaid H, Klip A, Cerasi E, Sasson S, 2017. Regulation of GLUT4 activity in myotubes by 3-O-methyl-dglucose. Biochim Biophys Acta, 1859: 1900-1910.

Tabatabaie PS, Yazdanparast R, 2017. Teucrium polium extract reverses symptoms of streptozotocin-induced diabetes in rats via rebalancing the $\mathrm{Pdx} 1$ and FoxO1 expressions. Biomed 
Pharmacother, 93: 1033-1039.

Zaid H, Antonescu CN, Randhawa VK, Klip A, 2008. Insulin action on glucose transporters through molecular switches, tracks and tethers. Biochem J, 413: 201-215.

Zaid H, Mahdi AA, Tamrakar AK, Saad B, Razzaque MS, Dasgupta A 2016. Natural active ingredients for diabetes and metabolism disorders treatment. Evid Based Complement Alternat Med, 2965214.

Zaid H, Saad B, 2013. State of the art of diabetes treatment in GrecoArab and Islamic medicine. In Ronald R Watson Victor R Preedy (Eds), Bioactive Food as Dietary Interventions for Diabetes San Diego, CA, USA and London, UK: Academic Press. 327-335.

Zaid H, Saad B, Mahdi AA, Tamrakar AK, Haddad PS, Afifi FU, 2015. Medicinal plants and natural active compounds for diabetes and/or obesity treatment. Evid Based Complement Alternat Med, 469762.

Zaid H, Silbermann M, Ben-Arye E, Saad B, 2012. Greco-Arab and Islamic herbal-derived anticancer modalities: from tradition to molecular mechanisms. Evid Based Complement Alternat Med, 349040.

Zaid H, Talior-Volodarsky I, Antonescu C, Liu Z, Klip A. 2009. GAPDH binds GLUT4 reciprocally to hexokinase-II and regulates glucose transport activity. Biochem J, 419: 475-484.

Zierath JR, He, L, Guma, A, Odegoard Wahlstrom E, Klip A, WallbergHenriksson H, 1996. Insulin action on glucose transport and plasma membrane GLUT4 content in skeletal muscle from patients with NIDDM. Diabetologia, 39: 1180-1189.
Citation: Kadan S, Sasson Y, Abu-Reziq R, Saad B, Benvalid S, Linn T, Cohen G, Zaid H, 2018. Teucrium polium extracts stimulate GLUT4 translocation to the plasma membrane in $\mathrm{L} 6$ muscle cells. Adv M ed Plant Res, 6(1): 1-8. 